Jurnal Hukum Mimbar Justitia

Fakultas Hukum Universitas Suryakancana

Vol. 4 No. 1 - Juni 2018, hlm. 112-127

ISSN: 2477-5681 (Cetak), ISSN: 2580-0906 (Online)

Open Access at: https://jurnal.unsur.ac.id/jmj

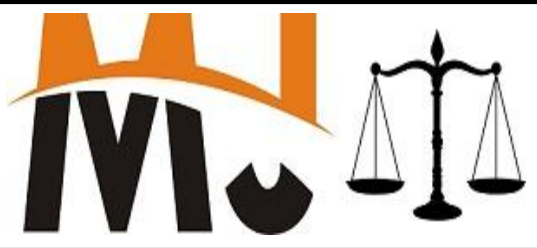

\title{
PELAYANAN PERIZINAN TERPADU DALAM MENINGKATKAN INVESTASI DAN PERTUMBUHAN UMKM
}

\author{
M. Budi Mulyadi \\ Universitas Suryakancana \\ Email: mbudimulyadi@gmail.com
}

Masuk: Maret 2018

Penerimaan: April 2018

Publikasi: Juni 2018

\begin{abstract}
ABSTRAK
Pemerintah harus menyusun strategi untuk meningkatkan kesejahteraan masyarakat. Dengan berbagai kebijakan dan pelayanan kepada masyarakat harus berorientasi pada peningkatan kesejahteraan masyarakat. Salah satu faktor untuk meningkatkan kesejahteraan masyarakat adalah diberikannya pelayanan perizinan yang baik, hal ini dapat meningkatkan secara kuantitas dan kwalitas pertumbuhan usaha mandiri masyarakat. Perizinan adalah instrumen pemerintah untuk mengendalikan aktivitas masyarakat, oleh karena itu perizianan memiliki peranan yang sangat besar untuk untuk membawa suatu daerah kearah yang lebih baik.
\end{abstract}

Kata Kunci: Pelayanan Perizinan, Wirausaha, Investasi, Peningkatan Kesejahteraan.

\section{ABSTRACT}

The Government should devise a strategy to enhance the welfare of society. With a variety of policy and services to the public must be oriented to the improvement of the welfare of the community. One of the factors to improve the welfare of society is it gives a good licensing services, this may increase in the quantity and quality of the growth of the independent business community. Licensing is the instrument of Government to control the activity of the society, therefore the licensing has a very big role for to bring an area towards the better.

Keywords: The Licensing Service, Self-employment, Investments, An Increase In Wellbeing.

\section{PENDAHULUAN}

Kesejahteraan merupakan tujuan utama dari berbagai negara, begitu pun Indonesia, dalam alinea ke- 4 Pembukaan Undang-undang Dasar 1945 Indonesia betujuan mensejahteraan kesejahteraan umum, kesejahteraan bersama $^{1}$ yang dan

Ahmad Hunaeni Zulkarnaen, 2016, Masalah Rawan Dalam Hubungan Industrial Dan Konsep Negara Kesejahteraan Indonesia, Jurnal Mimbar Justitia Fakultas Hukum 
M. Budi Mulyadi

Jurnal Hukum Mimbar Justitia

Vol. 4 No. 1 - Juni 2018

menghindari ketimpangan kesejahteraan yang jauh.

Kesejahteraan sosial merupakan suatu keadaan dimana terpenuhinya kebutuhan hidup yang layak bagi masyarakat, sehingga terpenuhinya kebutuhan hidup yang dapat mengembangkan diri dan melaksanakan fungsi sosial yang dapat dilakukan oleh pemerintah maupun pemerintah daerah, masyarakat dalam bentuk pelayanan sosial yang meliputi rehabilitasi sosial, jaminan sosial, pemberdayaan dan perlindungan sosial. $^{2}$

Adapun menurut Badan Pusat Statistik adalah suatu kondisi dimana seluruh kebutuhan jasmani dan rohani dari rumah tangga dapat terpenuhi sesuai dengan tingkat hidup. Kesejahteraan sosial menjadi sebuah topik yang tidak habisnya dibahas, menjadi tema sentral dalam tiap kajian dalam forum-forum ilmiah maupun politik, hal ini karena sebagian dari masyarakat masih belum terpenuhi hakhaknya untuk mendapatkan hidup yang

Universitas Suryakancana, Vol. 2 No. 2, Desember, hlm. 807.

2 Undang-undang Nomor 11 tahun 2009 tentang Kesejahteraan Sosial Pasal 1 dan Pasal 2. layak, hak mendapatkan pendidikan dan kesehatan.

Untuk

meningkatkan kesejahteraan masyarakat berbagai upaya dan kajian dilakukan, pemerintah dan para ilmuan mencari solusi atas masalah kesejahteraan yang belum menjangkau lapisan masyarakat, kajian dari berbagai presfektif dilakukan, ada banyak faktor untuk meningkatkan kesejahteraan diantaranya adalah kemandirian masyarakat untuk mengupayakan kesejahteraannya dengan menjadi wirausaha dan menimgkatkan iklim investasi. Di negara-negara maju jumlah pengusahanya memiliki presentase yang cukup besar jika dibandingkan dengan negara-negara berkembang seperti Indonesia. Jumlah pengusaha berada di angka $1,65 \%$ dari jumlah populasi penduduk, sedangkan negara tetangga terdekat seperti Singapura sekitar 7\%, Malaysia $5 \%$ dan Thailand $3 \% .^{3}$ Dengan jumlah Pengusaha di Indonesia

\footnotetext{
Samsul Rizal, Pernyataan Rektor Universitas Syiah Kuala (Unsyiah) Darussalam Banda Aceh, di Acara Wisuda AAC Dayan Dawood Darussalam, Banda Aceh, diakses pada http://www.republika.co.id/berita/pendidik an/dunia-kampus/15/08/27/ntpdoq334rektor pengusaha-di-indonesia-165-persensingapura-7-persen-penduduk, diakses pada tanggal Kamis 27 Augustus 2015, 14:15 WIB
} 
M. Budi Mulyadi

Jurnal Hukum Mimbar Justitia

Vol. 4 No. 1 - Juni 2018

masih kurang dari $2 \%$ maka akan sulit untuk menjadikan Indonesia sebagai negara maju, mayoritas masyarakat masih memilih untuk menjadi pekerja dibanding berusaha sendiri mendirikan usahanya atau berwirausaha. Sehingga pertumbuhan ekonomi memiliki kecendrungan untuk melambat. ${ }^{4}$

Sebagai faktor penghambat mengapa minat menjadi wirausaha itu masih rendah adalah faktor internal yang berasal dari motivasi orang tersebut dan ada faktor eksternal yaitu dapat berasal dari kebijakan pemerintah maupun pengaruh lingkungan sekitar. Berbicara tentang kebijakan pemerintah tentu ada banyak kebijakan untuk mendorong dan menumbuhkan jiwa wirausaha dengan bantuan modal, pinjaman lunak, pendidikan, pelatihan, pendampingan, dan kebijakan perizinan.

Selaras dengan kebijakan Presiden tentang Perizinan guna meningkatkan iklim investasi dan peningkatan ekonomi dengan paket kebijakan ekonomi yang bertujuan untuk

4 Mia Amalia, 2017, Kebijakan Hukum Terhadap Pelaksanaan Pengampunan Pajak (Tax Amnesty) Dalam Meningkatkan Kesejahteraan Masyarakat Bangsa Indonesia, Jurnal Hukum Mimbar Justitia Fakultas Hukum Universitas Suryakancana, Vol. 3 No. 1, Juni, hlm. 18 meningkatkan kesejahteraan masyarakat. Kebijakan ini bertujuan untuk meningkatakan tingkat kwalitas pelayanan perintah dalam pengurusan izin agar lebih mudah, efisien, terintegrasi dengan menggunakan teknologi informasi, namun tidak keluar dari sistem tata kelola pemerintahan yang baik.

Sistem yang coba dicanangkan dengan mempermudah pelayanan perizinan, dengan standar waktu yang jelas dalam proses penerbitan izin, memiliki standar kebiajakn biaya yang lebih terjangkau dan jelas, meningkatkan koordinasi dan singkronisasi antar lembaga, baik dalam hubungannya yang vertikal yaitu antara kelembagaan pusat dan daerah, maupun horizontal yaitu antar lembaga yang satu dengan yang lainnya seperti satu dinas dengan dinas-dinas di lingkungan pemerintahan.

Tujuan yang hendak dicapai dngan memperbaiki sistem pelayanan perizinan yang belum optimal misalnya perizinan masih bersipat parsial atau tidak terintegrasi, sekuensial (berurutan), belum seluruhnya menggunakan perangkat teknologi informasi (online), belum jelasnya 
M. Budi Mulyadi

Jurnal Hukum Mimbar Justitia

Vol. 4 No. 1 - Juni 2018

standar harga dan standar waktu proses penerbitan izin serta, karakter dari para pelaksana di tubuh birokrat masih memiliki paradigma sebagai "pemberi izin" bukan "melayani.",

Permasalahan perizinan harus mendapatkan perhatian yang lebih serius, karena menyangkut tumbuh dan berkembangnya perekonomi masyarakat dan pertumbuhan ketertarikan asing untuk menanamkan modalnya di Indonesia.

Izin adalah persetujuan dari penguasa berdasarkan Undang-Undang atau peraturan Pemerintah untuk dalam keadaan tertentu menyimpang dari larangan umum tersebut. Izin adalah instrumen pemerintah dalam rangka menyelenggarakan pemerintahan dalam mengatur kepentingan umum. Izin adalah seperangkat peraturan yang berisi tentang perkenaan atau izin. ${ }^{6}$

5 Mia Chitra Dinisari (editor), Pemerintah Luncurkan Paket Kebijakan Ekonomi Percepatan Pelaksanaan Berusaha, http://finansial.bisnis.com/read/20170831/ 9/685850/pemerintah-luncurkan-paketkebijakan-ekonomi-percepatanpelaksanaan-berusaha, diakses pada tanggal 9 Juni 2018 pukul 10.52 WIB.

6 Suwari Akhmaddhian, 2012, Pengaruh Reformasi Birokrasi Terhadap Perizinan Penanaman Modal Di Daerah (Studi Kasus Di Pemerintahan Kota Bekasi), Jurnal Dinamika Hukum FH Universitas Jendral
II. PEMBAHASAN

A. Sistem Perizinan yang Terpadu.

Perkembangan ekonomi dan meningkatnya iklim investasi suatu daerah tidak lepas dari banyaknya perusahaan baik dari skala mikro maupun yang besar untuk tumbuh di daerah tersebut terhubung dengan sistem pelayanan perizinan yang diberikan oleh pemerintah, baik di level pemerintah pusat maupun daerah. Sistem birokrasi dalam sistem perizinan terntu akan terhubung dari satu bagian ke bagian yang lain.

Satu perusahaan yang berdiri memerlukan izjin yang tidak hanya satu jenis izin saja yang ada namun memerlukan berbagai izin sesuai dengan jenis dan cakupan usaha dari perusahaan tersebut, sehingga akan memerlukan jenis izin yang banyak. Sebagai contoh perusahaan makanan ringan akan memiliki izin yang tidak sedikit, mulai tempat usaha memerlukan izin bangunan, izin peruntukan penggunaan tanah, izin gangguan, izin tempat usaha dan izin lainnya kemudian dari produknya tentu juga akan dikenai berbagai macam izin seperti izin dari

Soedirman, Vol. 12 No. 3, September, hlm. 469. 
M. Budi Mulyadi

Jurnal Hukum Mimbar Justitia

Vol. 4 No. 1 - Juni 2018

dinas kesehatan, izin Pangan Industri Rumah Tangga (PIRT), bahkan ada dari MUI (Majelis Ulama Indonesia) yang mengeluarkan sertikat Halal. Permasalahan yang lain adalah untuk satu izin akan berkaitan dengan dinas dinas lain pula yang membidanginya.

Dewasa ini jenis dan prosedur perizinan di Indonesia masih beraneka ragam, rumit, dan sukar ditelusuri, sehingga sering merupakan hambatan bagi kegiatan dunia usaha. Jenis perizinan di Negara Indonesia sedemikian banyaknya. Namun, bukan berarti dengan wewenang yang dimiliki oleh pemerintah pusat atau daerah dapat memberikan izin sebanyak-banyaknya tanpa mempertimbangkan aspek lain. ${ }^{7}$

\section{Permasalahan tentang} kewenanganyapun ini sering menjadi masalah, misalnya suatu izin apakah menjadi kewenangan tingkat kabupaten,

7 Asri Hikmatuz Zulfa, 2015, Upaya Penerapan Sanksi Hukum Administrasi Badan Pelayanan Perizinan Terpadu Kabupaten Nganjuk Terhadap Penyelenggaraan Reklame Tanpa Izin (Studi di Badan Pelayanan Perizinan Kabupaten Nganjuk), Jurnal Hukum Student Journal Fakultas Hukum Universitas Brawijaya, Archives Februari, hlm. 13. diakses pada http://hukum.studentjournal.ub.ac.id/index .php/hukum /article/view/970/959; Lihat juga Helmi, 2012, Hukum Perizinan Lingkungan Hidup, Sinar Grafika, Jakarta, hlm. 79. tingkat provisi atau tingkat pusat. Permasalahan kewenangan ini biasanya terkait dengan jenis usaha, kapasitas dan cakupan wilayah usaha yang dilakukan.

Peran birokrasi publik tidak hanya memberi pelayanan kepada masyarakat dalam arti sempit, tetapi berperan mengelola kebijakan publik. Biokrasi publik sangat berperan dalam proses formulasi/pembuatan kebijakan publik, pelaksanaan dan penegakkan, serta evaluasinya. Dari peran brokrasi publik, apa yang dilakukan oleh "pelaksana terdepan" hanya menjalankan sebagian kecil dari pelaksanaan kebijakan publik. $^{8}$

Untuk mengatasi permasalahan tentang birokrasi perijianan yang berbelit-belit pemerintah menerbitkan Peraturan Menteri Dalam Negeri Nomor 24 tahun 2006 tentang Pedoman Penyelenggaraan Pelayanan Terpadu Satu Pintu (PTSP). Peraturan menteri ini sebagai acuan bagi pemerintah daerah untuk membangun sistem

8 Ronni Juwandi, 2016, Efektivitas Badan Pelayanan Perizinan Terpadu Kota Bandung Dalam Rangka Reformasi Birokrasi, Untirta Civic Education Journal (UCEJ), Vol. 1, No. 2, Desember, hlm. 166, Lihat Juga Sedarmayanti, 2009, Reformasi Administrasi Publik, Reformasi Birokrasi, dan Kepemimpinan Masa Depan, Refika Aditama, Bandung. 
M. Budi Mulyadi

Jurnal Hukum Mimbar Justitia

Vol. 4 No. 1 - Juni 2018

perizinan satu pintu, artinya dengan sistem yang memangkas sistem birokrasi yang berbelit belit.

Apalagi masyarakat menilai bahwa pelayanan publik yang diselenggarakan oleh pemerintah lama, berbelit-belit, dengan dengan persyaratan yang rumit dan regulasi yang tidak fleksibel. ${ }^{9}$

Tidak setiap daerah memiliki visi yang sama untuk membangun daerah dengan memberikan pelayanan yang sederhanan murah dan mudah bagi masyarakat, karena bagi sebagai pemerintah daerah memaknai sistem perijian adalah sistem untuk mendapatkan PAD (Pendapatan Asli Daerah) yang besar. Padahal pemberian pelayanan kepada masyarakat merupakan kewajiban utama bagi pemerintah. $^{10}$

9 Nuria Siswi Enggarani, 2016, Kualitas Pelayanan Publik dalam Perizinan di Pelayanan Terpadu Satu Pintu (PTSP) Kantor Badan Penanaman Modal dan Pelayanan Perizinan Terpadu (BPMP2T) Kabupaten Boyolali, Jurnal Law and Justice Fakultas Hukum Universitas Muhammadiyah Surakarta, Vol. 1 No. 1, hlm. 18.

10 Raisa Harly Runida Agustine, 2014, Pengaturan Pelayanan Perizinan Terpadu Satu Pintu Dalam Upaya Meningkatkan Investasi Di Provinsi Lampung, Jurnal HIMA HAN Fakultas Hukum Bagian Hukum Administrasi Negara Universitas Lampung, Vol. 1, No. 1, hlm. 7.
Dengan iklim otonomi daearah Pemerintah Daerah di dorong untuk dapat menghidupi daerahnya menjadi lebih mandiri. Sehingga Pemerintah Daerah berusaha meningkatkan pendapatan asli daaerahnya dengan mengenakan tarif perizinan yang tinggi, selain itu disetiap dinas juga memiliki target pendapat sendiri sendiri yang harus dipenuhi, sehingga ego sentris tiap dinas berefek birokrasi yang berbelit belit.

Dengan berlakunya sistem otonomi daerah memunculkan egosentris dari pemerintah kabupaten dan kotamadya yang memiliki kewenangan yang besar untuk menerbitkan izin-izin dibandingkan dengan pemerintah provinsi. Karena itu ada beberapa daearah yang lambat merespons perubahan program sistem perizinan di daerah yang sesuaikan dengan pedoman yang telah ditentukan oleh pemerintah pusat melalui aturan di atas.

Perizinan satu pintu memungkinkan proses pelayanan perizinan yang diberikan sangat singkat dengan harga yang jelas dan menghindari praktek-praktek pungli, masyarakat dapat memantau 
M. Budi Mulyadi

Jurnal Hukum Mimbar Justitia

Vol. 4 No. 1 - Juni 2018

perkembangan proses penerbitan izin yang diajukan, apalagi perkembangan teknologi yang terintegrasi antar satu dinas ke dinas yang lain mejadikan sistem pelayanan perizinan menjadi lebih baik lagi.

\section{Bahkan Presiden Joko Widodo} mendorong Gubernur agar iklim investasi terus meningkat dengan membangun sistem pelayanan perizinan terpadu satu pintu, dan juga memberikan hukuman bagi daerah yang belum membangun sistem pelayanan terpadu satu pintu itu dengan menghapus dana alokasi khusus, termasuk mengurangi jumlah Dana Alokasi Umum (DAU) untuk daerah tersebut. Sistem pelayanan Terpadu Satu Pintu merupakan kebijakan yang telah lama dikeluarkan pada era Pemerintahan Presiden Susilo Bambang Yudhoyono, kemudian berkembangan lagi dengan dikeluarnya Undang-undang Nomor 25 tahun 2009 tentang Pelayanan Publik. ${ }^{11}$

\section{Penyelenggaraan Pelayanan} Terpadu Satu Pintu (PPTSP) adalah

11 Antonius Tarigan, Dilema Birokrasi Satu Pintu,

http://nasional.kompas.com/read/2015/01/ 08 /19033681/Dilema.Birokrasi.Satu.Pintu, diakses pada tanggal 6 Mei 2018, Pukul 9:47 WIB. kegiatan penyelenggaraan perizinan dan non perizinan yang proses pengelolaannya mulai dari tahap permohonan sampai ke tahap terbitnya dokumen dilakukan dalam satu tempat. ${ }^{12}$ Sistem pelayanan yang cepat, mudah dan murah adalah paradigma yang harus dikedepankan oleh para pemerintah terutama pemerintah di tingkat Kabupaten dan Kotamadya karena pada tingkat inilah diberikan kewenangan yang lebih besar tentang pemberian izin, terutama izin usaha dan investasi.

Perjinan Terpadu yang saat ini terus dilakukan perbaikan, karena dilapangan ditemukan berbagai permasalahan yang terjadi, yaitu :

a. Tidak semua kepada daerah atau kepada dinas melimpahkannya kewenangannya ke sekretariat Pelayanan Perizinan ini. Menurut

12 Evy Urmilasari, Andi M. Rusli, 2013, Analisis Pelayanan Perizinan di Badan Perizinan Terpadu dan Penanaman Modal Kota Makassar, Government: Jurnal IImu Pemerintahan Universitas Hasanuddin, ISSN 1979-5645, Volume. 6, Nomor. 1, Januari, hlm. 50., lihat juga: Sri Agustina Rumapea dan Kridanto Surendro, 2007, Perencanaan Arsitektur Enterprise Penyelengaraan Pelayanan Terpadu Satu Pintu (Usulan: Dinas Perizinan), Seminar Nasional Aplikasi Teknologi Informasi (SNATI 2007); Pelayanan Satu Pintu Plus di Kabupaten Solok, hlm. 1. 
M. Budi Mulyadi

Jurnal Hukum Mimbar Justitia

Vol. 4 No. 1 - Juni 2018

Badan Koordinasi Penanaman

Modal pada tahun 2013 baru 41\% pemerintah daerah yang mendelegasikan kewenangannya ke PTSP. Sebagai besar kepada daerah dan dinas beralasan terait kepentingan dinas yang spesifik yang bebeda dengan lain, sehingga perlu penanganan yang khusus yang terpisah dari PTSP untuk izin tersebut.

b. Keterbatasan sumber daya manusia, dalam sistem PTSP harus memiliki akses ketiap dinas dengan sumbedaya manusia yang memiliki akses kearah sana, namun adakalanya keterbatasan sumberdaya yang dimiliki di PTSP sangat terbatas, misal tidak memiliki tenaga ahli pada bidangbidang tertentu misal ahli bidang geologi, ahli bidang lingkungan, ahli bidang kesehatan dan lainnya.

c. Setiap pemerintahan daerah ditiap daerah memiliki kewenangan yang berbeda dan cara pandang yang berbeda antara daerah yang satu dengan yang lainnya, sehingga status kelembagaan PTSP ada yang berbentuk Dinas, Kantor, Badan dengan implikasi yang berbeda-beda. Efek dari hal itu tentu berbeda, misalkan berbentuk Dinas maka akan lebih mudah berkoordinasi dengan dinas yang lain karena kedudukannya setara dengan dinas yang lain, namun jika berbentuk kantor atau hanya badan maka memikiki kedudukan yang lebih rendah dibanding dinas sehingga menyulitkan berkoordinasi, bahkan ada yang lebih parah lagi ketika PTSP hanya berupa unit yang menempel pada lembaga lain.

d. Disharmoni regulasi, PTSP dibentuk sebagai pengejawantahan dari Peraturan Menteri Dalam Negeri Nomor 24 tahun 2006 tentang Pedoman Penyelenggaraan Pelayanan Terpadu Satu Pintu, kemudian mengeluarkan Peraturan Menteri Dalam Negeri Nomor 20 tahun 2008 tentang Pedoman Organisasi dan Tata Kerja Pelayanan Terpadu di Daerah. Dalam aturan yang lain yang dikeluarkan oleh Presiden melalui Peraturan Presiden Nomor 27 tahun 2009 tentang PTSP di Bidang 
Penanaman Modal. Peraturan

tersebut mengatur objek yang

sama namun peraturan dan

kewenangnya berbeda sehingga

menimbulkan adanya tumpang

tindih aturan. Misalnya dalam

kewenangannya ada dua komando

yaitu Menteri Dalam Negeri

dengan Badan Koordinasi

Penanaman Modal (BKPM) yang

meiliki kewenangan yang

tumpang tindih. ${ }^{13}$

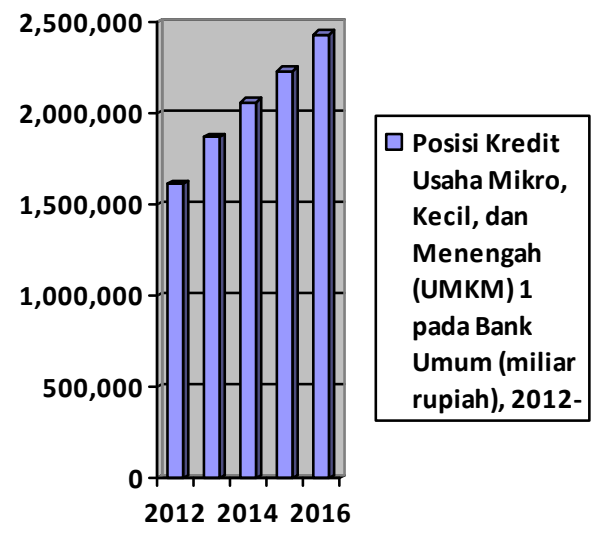

\section{B. Tuntutan Peningkatan Iklim Investasi Dan Perkembangan Ekonomi.}

Tabel 1. Jumlah Total Posisi Kredit

Sistem perizian yang cepat, mudah dan murah terus menerus Usaha Mikro, Kecil, dan Menengah

ditingkatkan, dorongan-dorongan dari

Pemerintah Pusat kepada Pemerintah

Daerah semakin kuat, karena walau secara umum ada kenaikan angka pada pencapaian investasi dan berkembangnya perekonomian melalui tumbuhnya usaha kecil dan menengah.

13 Antonius Tarigan, Dilema Birokrasi ..., Op.Cit. 
M. Budi Mulyadi

Jurnal Hukum Mimbar Justitia

Vol. 4 No. 1 - Juni 2018

Dengan perincian sebagai berikut :

\begin{tabular}{|c|c|c|c|c|c|}
\hline Rincian & 2012 & 2013 & 2014 & 2015 & 2016 \\
\hline \multicolumn{6}{|l|}{ UMKM } \\
\hline \multicolumn{6}{|l|}{ Lapangan Usaha } \\
\hline $\begin{array}{l}\text { Pertanian, Peternakan, } \\
\text { Kehutanan, dan Perikanan }\end{array}$ & 43609 & 51912 & 58658 & 65530 & 71776 \\
\hline Pertambangan dan Penggalian & 5427 & 4753 & 4763 & 4838 & 4703 \\
\hline Industri Pengolahan & 59500 & 60084 & 67558 & 76518 & 84195 \\
\hline Listrik, Gas, dan Air Bersih & 1474 & 1750 & 2187 & 2079 & 2501 \\
\hline Konstruksi & 30594 & 38780 & 40614 & 43246 & 48188 \\
\hline $\begin{array}{l}\text { Perdagangan, Hotel, dan } \\
\text { Restoran }\end{array}$ & 262584 & 341354 & 376342 & 422013 & 463443 \\
\hline Pengangkutan dan Komunikasi & 20219 & 23882 & 24033 & 25488 & 26728 \\
\hline $\begin{array}{l}\text { Keuangan, Real Estat, dan Jasa } \\
\text { Perusahaan }\end{array}$ & 40465 & 46003 & 48665 & 51858 & 52883 \\
\hline Jasa-Jasa & 62524 & 40449 & 48900 & 48230 & 47640 \\
\hline Tidak Teridentifikasi & - & 1062 & 0 & 1 & 14 \\
\hline \multicolumn{6}{|l|}{ Jenis Penggunaan } \\
\hline Modal Kerja & 403047 & 445235 & 490262 & 537186 & 587312 \\
\hline Investasi & 123350 & 164792 & 181459 & 202615 & 214760 \\
\hline Tidak Teridentifikasi & 0 & 1 & - & 0 & 0 \\
\hline \multicolumn{6}{|l|}{ Skala Usaha } \\
\hline Mikro & 97177 & 118767 & 140272 & 164869 & 182876 \\
\hline Kecil & 164273 & 187729 & 201976 & 215925 & 241460 \\
\hline Menengah & 264947 & 303533 & 329473 & 359008 & 377737 \\
\hline \multicolumn{6}{|l|}{$\begin{array}{c}\text { Kredit dengan Penjaminan } \\
\text { Tertentu }\end{array}$} \\
\hline Mikro & 17161 & 23536 & 26967 & 10816 & 6078 \\
\hline Kecil & 20149 & 20416 & 19375 & 8461 & 22945 \\
\hline \multirow[t]{2}{*}{ Menengah } & 2447 & 2641 & 1960 & 2502 & 1902 \\
\hline & 1.618 .947 & 1.876.679 & 2.063 .464 & 2.241.183 & 2.437 .141 \\
\hline
\end{tabular}

Tabel 2. Posisi Kredit Usaha Mikro, Kecil, dan Menengah (UMKM) pada Bank Umum (miliar rupiah), 2012-2016. ${ }^{14}$

14 Badan Pusat Statistik, https://www.bps.go.id/statictable/2015/09/30/1876/posisi-kredit-usahamikro-kecil-dan-menengah-umkm-1-pada-bank-umum-miliar-rupiah-2012-2016.html, diakses pada tanggal 8 Mei 2018, pukul 10.35 WIB. 


\begin{tabular}{|c|c|c|c|}
\hline \multicolumn{2}{|c|}{} & $\begin{array}{r}\text { M. B } \\
\text { Jurnal Huk } \\
\text { Vol. 4 }\end{array}$ \\
\hline \hline No & Tahun & Proyek & Investasi \\
\hline 1 & 2006 & $\mathbf{1 6 4}$ & $\mathbf{2 0 ~ 7 8 8 , 4}$ \\
\hline 2 & 2007 & $\mathbf{1 5 9}$ & $\mathbf{3 4 ~ 8 7 8 , 7}$ \\
\hline 3 & 2008 & $\mathbf{2 3 9}$ & $\mathbf{2 0 3 6 3 , 4}$ \\
\hline 4 & 2009 & $\mathbf{2 4 8}$ & $\mathbf{3 7 ~ 7 9 9 , 8}$ \\
\hline 5 & 2010 & $\mathbf{8 7 5}$ & $\mathbf{6 0 6 2 6 , 3}$ \\
\hline 6 & 2011 & $\mathbf{1 3 1 3}$ & $\mathbf{7 6 ~ 0 0 0 . 7}$ \\
\hline 7 & 2012 & $\mathbf{1 2 1 0}$ & $\mathbf{9 2 ~ 1 8 2 , 0}$ \\
\hline 8 & 2013 & $\mathbf{1 6 5 2}$ & $\mathbf{1 2 8} 150,6$ \\
\hline 9 & 2014 & $\mathbf{2 1 2 9}$ & $\mathbf{1 5 6 1 2 6 , 3}$ \\
\hline 10 & 2015 & $\mathbf{5 1 0 0}$ & $\mathbf{1 7 9} \mathbf{4 6 5 , 9}$ \\
\hline 11 & 2016 & $\mathbf{7 5 1 1}$ & $\mathbf{2 1 6 ~ 2 3 0 , 8}$ \\
\hline & & & \\
\hline
\end{tabular}

Tabel 3. Realisasi Investasi Penanaman Modal Dalam Negeri Menurut Provinsi 1 (miliar rupiah), 2006-2016. ${ }^{15}$

Kenaikan tersebut belum memenuhi target yang telah ditetapkan antara lain investasi negara-negara lain ke Indonesia masih rendah yaitu sekitar $1,97 \%$ dari data 2012-2016 yaitu sebesar USD 1.417,58 Milyar, dan capaian target rasio investasi sebesar $32,7 \%$ di tahun 2012-2016 di bawah target RPJMN sebesar 38,9\% pada tahun 2019. Kemudian realisasi investasi masih rendah dibandingkan

15 Badan Pusat Statistik,
https://www.bps.go.id/statictable/2014/09 /17/1336/realisasi-investasi-penanamanmodal-dalam-negeri-menurut-provinsi--sup1--sup---miliar-rupiah---2006-2016.html, diakses pada tanggal 8 Mei 2018? pukul 10.35 WIB. dengan pengajuan/komitmen investasi untuk (Penanaman Modal Asing) PMA 27,5\% dan (Penanaman Modal Dalam Negeri) PMDN 31,8\% (2010-2016), serta belum seimbangnya wilayah investasi di mana investasi di Jawa di atas $50 \%$ dibandingkan dengan Luar Jawa.

Oleh sebab itu, kendati Indonesia sudah masuk sebagai negara layak investasi, namun realisasi dan kecepatan untuk mulai berusaha belum seperti yang diharapkan. Menurut Laporan Global Competitiveness Report 20122013 menunjukkan, inefficient government bureaucracy di Indonesia tertinggi dalam daya saing bisnis. Bobotnya, 15,4\% lebih besar dari masalah korupsi (14,2\%) serta infrastruktur (8,7\%). Akibatnya, Indonesia hanya menempati posisi ke50 dari 144 negara pada 2013, sedangkan Malaysia di posisi ke-25, Thailand ke-38, Tiongkok ke-29, Jepang ke-10, dan Singapura ke-2. ${ }^{16}$

Dengan peringkat tersebut tentu hal ini bukan prestasi yang layak dibanggakan, masih banyak kendalakendalam dalam sistem pelayanan

\footnotetext{
16 Mia Chitra Dinisari, Pemerintah Luncurkan Paket Kebijakan..., Op.Cit,.
} 
M. Budi Mulyadi

Jurnal Hukum Mimbar Justitia

Vol. 4 No. 1 - Juni 2018

perizinan dan investasi. Ketertarikan para investor asing tentu dilihat dari faktor-faktor yang mendorong mereka untuk menanamkan usahanya di Indonesia yaitu: Perizinan yang cepat, mudah dan murah; kepastian hukum; biaya produksi dan tenaga kerja yang murah; keamanan negara; dan faktor lainnya.

Perizinan yang cepat akan sangat berpengaruh bagi pengusaha, karena hitungan waktu menentukan kapan Break Event Point (BEP) atau kembali modal terjadi. Target waktu yang dicapai dalam penyelesaian izin harus jelas dan transparan, dan tidak menjebak pemohon izin dengan waktu yang tidak dicantumkan dengan jelas yang bertujuan untuk memungut pungutan-pungutan ilegal. Sistem tarif harga yang jelas dan tertera dalam daftar yang dapat dilihat oleh masyarakat secara terbuka dan secara konsekuen dilaksanakan oleh pemerintah daerah. Biaya proses perizinan adalah salah satu tolak ukur yang paling utama bagi masyarakat untuk mengajukan izin, dengan biaya yang tidak jelas apalagi pemerintah daerah masih memiliki paradigma bahwa biaya pengurusan perizinan perlu terus ditingkatkan untuk menunjang pendapatan asli daerah, sehingga harga proses perizinan menjadi melambung tinggi dan sangat memberatkan masyarakat. Tentu hal tersebut menjadi bertolak belakang dengan visi yang hendak dicapai, untuk meningkatkan Pendapatan Asli Daerah (PAD) yang besar, titik tindaknya bukan dari pra usaha yaitu ketika perizinan dibuat, namun hendaknya diambil melalui mekanisme retribusi dan pajak setalah izin diterbitkan.

\section{Peningkatkan Ekonomi Dengan Pelayanan Perizinan Yang Baik.}

Dalam Undang-undang Nomor 23 tahun 2014 tentang Pemerintahan Daerah mengamanatkan untuk memberikan pelayanan sektor publik guna mempercepat terwujudnya kesejahteraan masyarakat melalui:

1. Peningkatan pelayanan,

2. Pemberdayaan, dan peranserta masyarakat, serta

3. Peningkatan daya saing daerah dengan memperhatikan prinsip demokrasi, pemerataan, keadilan, dan kekhasan suatu daerah dalam 
M. Budi Mulyadi

Jurnal Hukum Mimbar Justitia

Vol. 4 No. 1 - Juni 2018

sistem Negara Kesatuan Republik

Indonesia. $^{17}$

Melalui peningkatan sistem Pelayanan Perijinan Terpadu yang berdampak pada peningkatan daya tampung tenaga kerja yang semakin besar, dan daya beli masyarakat yang semakin meningkat. Peningkatan ini terjadi karena semakin mudahnya masyarakat melakukan kegiatan usaha. Dengan sistem perizinan yang cepat dan murah menjadikan daerah ini maju pesat dalam peningkatan investasi dan usaha. Inovasi layanan sistem perizinan yang diberikan memberikan kepuasan pelayanan yang terintegrasi, dengan menggunakan sistem pelayanan online yang terintegrasi, sehingga masyakarakat terlayani dengan sangat cepat.

Salah satu contoh daerah yang berhasil dengan sistem pelayanan perizinan yang menjadi rujukan bagi daerah-daerah lain menurut Badan Koordinasi Penanaman Modal (BKPM)

17 Dinas Penanaman Modal Dan Pelayanan Terpadu Satu Pintu Provinsi Jawa Barat, Penyelenggaraan Pelayanan Perizinan, Kegiatan Forum Perangkat Daerah Thn 2018, Mason Fine Hotel, 6-3-2018, hlm. 10 diakses pada https://dpmptsp.jabarprov.go.id/web/applicat ion/modules/arsip/files/7de2b7807a3bb4fecd 15fe5b59f684c7. diakses pada tanggal 6 juli 2018, pukul 15:53 WIB. yaitu Kabupaten Surakarta dan Kabupaten Sragen di Jawa Tengah. Di Kabpaten Sragen Sistem pelayanan perizinan yang cepat bahkan inovasi kebijakan program layanan periziznan di sebuat dengan istilah SEMEDI denan kepanjangannya Sehari Mesti Jadi dimana dalam inovasi pelayanannya yaitu dengan memberikan pelayanan perizinan sehari selesai. ${ }^{18}$

PTSP Kabupaten Kabupaten Sragen yang memberikan pelayanan cepat dan transfaran mengakibatkan peningatan invetasi yang terus meningkat dari tahun ke tahun, sebagai contoh untuk izin prinsif investasi dengan rencana investasi sebesar Rp. 635 milyar pada tahun 2013, kemudian pada tahun berikutnya 2014, mengalami peningkatan menjadi Rp. 1,5 triliun. Terjadi peningkatan yang signifikan atas investasi dan pertumbuhan usaha dikarena sistem pelayanan perizinan yang mudah, murah dan cepat. ${ }^{19}$

18 Margye J Waisapy, BKPM: Inovasi PTSP Surakarta dan Sragen Jadi Percontohan, Selasa, 16 Juni 2015, 00:59 WIB, http://www.beritasatu.com/ekonomi/282835bkpm-inovasi-ptsp-surakarta-dan-sragenjadi-percontohan.html diakses pada tanggal 6 Juli 2018, pukul 14:29 WIB.

19 Septian Deny, Investasi di Sragen Alami Peningkatan Signifikan, dibuat pada 15 Juni 2015, 14:53 WIB, diakses pada https://www.liputan6.com/bisnis/read/22521 
III. PENUTUP

\section{A. Kesimpulan}

Perizinan merupakan sebuah instrument yang dimiliki pemerintah untuk mengendalikan masyarakat, terutama dalam mengendalikan pada aktifitas ekonomi dan sosial. Untuk meningkatkan perekonomian masyarakat dan meningkatkan iklim investasi pemerintah harus mengupayakan pelayanan perizinan yang lebih mudah, murah dan cepat. Dukungan biaya yang murah, mudah dan cepat akan menarik para pengusaha dan investor untuk menginvestasikan usahanya di daerah tersebut.

Pemerintah mengupayakan agar seluruh pemerintah daerah dapat memberikan pelayanan perizinan terpadu agar meningkatkan iklim investasi dan penanaman modal. Bahkan memberikan sanksi bagi daerah yang belum menerapkan sistem pelayanan perizinan terpadu kepada masyarakat.

\section{B. Saran}

Pemerintah daerah hendaknya meningkatkan pelayanan perizinan kepada masyarakat dengan cara :

72/investasi-di-sragen-alami-peningkatansignifikan, diakses pada tanggal 6 Juli 2018 Pukul 15:57 WIB. a. Membuat sistem pelayanan perizinan yang terpadu dengan maksimalkan teknologi informasi, sehingga pelayanan perizinan kepada masyarakat dapat dapat dijalankan dengan cepat, mudah dan murah;

b. Pemerintah daerah mengupayakan dinas-dinas yang ada dalam lingkungan kewenangannya yang didalamnya terdapat pelayanan perizinan agar dapat diintegrasikan dalam pelayanan terpadu satu pintu, sehingga masyarakat cukup datang ke kantor Perizinan saja, tidak perlu datang ke dinas-dinas yang lain.

\section{DAFTAR ISI}

\section{A. Buku}

Helmi, 2012, Hukum Perizinan Lingkungan Hidup, Sinar Grafika, Jakarta.

Sedarmayanti, 2009, Reformasi Administrasi Publik, Reformasi Birokrasi, dan Kepemimpinan Masa Depan, Refika Aditama, Bandung.

\section{B. Peraturan \\ Undangan}

Undang-Undang Dasar 1945.

Undang-undang Nomor 25 tahun 2009 tentang Pelayanan Publik.

Undang-undang Nomor 11 tahun 2009 tentang Kesejahteraan Sosial 
C. Jurnal, Makalah, Internet dan Lain-lain.

Ahmad Hunaeni Zulkarnaen, 2016, Masalah Rawan Dalam Hubungan Industrial Dan Konsep Negara Kesejahteraan Indonesia, Jurnal Mimbar Justitia Fakultas Hukum Universitas Suryakancana, Vol. 2 No. 2, Desember.

Antonius Tarigan, Dilema Birokrasi Satu Pintu, http://nasional.kompas.com/read/2 015/01/08

/19033681/Dilema.Birokrasi.Satu. Pintu, diakses pada tanggal 6 Mei 2018, Pukul 9:47 WIB.

Asri Hikmatuz Zulfa, 2015, Upaya Penerapan Sanksi Hukum Administrasi Badan Pelayanan Perizinan Terpadu Kabupaten Nganjuk Terhadap Penyelenggaraan Reklame Tanpa Izin (Studi di Badan Pelayanan Perizinan Kabupaten Nganjuk), Jurnal Hukum Student Journal Fakultas Hukum Universitas Brawijaya, Archives Februari.

Badan Pusat Statistik, https://www.bps.go.id/statictable/ 2014/09/17/1336/realisasiinvestasi-penanaman-modaldalam-negeri-menurut-provinsi-sup-1--sup---miliar-rupiah--2006-2016.html, diakses pada tanggal 8 Mei 2018, pukul 10.35 WIB.

Badan Pusat Statistik, https://www.bps.go.id/statictable/ 2015/09/30/1876/posisi-kreditusaha-mikro-kecil-dan-menengahumkm-1-pada-bank-umum-miliar- rupiah-2012-2016.html, diakses pada tanggal 8 Mei 2018, pukul 10.35 WIB.

Dinas Penanaman Modal Dan Pelayanan Terpadu Satu Pintu Provinsi Jawa Barat , Penyelenggaraan Pelayanan Perizinan, Kegiatan Forum Perangkat Daerah Thn 2018, Mason Fine Hotel, 6-3-2018, hlm. 10 diakses pada https://dpmptsp.jabarprov.go.id/w eb/application/modules/arsip/files/ 7de2b7807a3bb4fecd

15fe5b59f684c7. diakses pada tanggal 6 juli 2018, pukul 15:53 WIB.

Evy Urmilasari, Andi M. Rusli, 2013, Analisis Pelayanan Perizinan di Badan Perizinan Terpadu dan Penanaman Modal Kota Makassar, Government: Jurnal Ilmu Pemerintahan Universitas Hasanuddin, Volume. 6, Nomor. 1, Januari.

Margye J Waisapy, BKPM: Inovasi PTSP Surakarta dan Sragen Jadi Percontohan, Selasa, 16 Juni 2015, 00:59 WIB, http://www.beritasatu.com/ekono mi/282835-bkpm-inovasi-ptspsurakarta-dan-sragen-jadipercontohan.html diakses pada tanggal 6 Juli 2018, pukul 14:29 WIB.

Mia Amalia, 2017, Kebijakan Hukum Terhadap Pelaksanaan Pengampunan Pajak (Tax Amnesty) Dalam Meningkatkan Kesejahteraan Masyarakat Bangsa Indonesia, Jurnal Hukum Mimbar Justitia Fakultas Hukum 
M. Budi Mulyadi

Jurnal Hukum Mimbar Justitia

Vol. 4 No. 1 - Juni 2018

Universitas Suryakancana, Vol. 3

No. 1, Juni.

Mia Chitra Dinisari (editor), Pemerintah Luncurkan Paket Kebijakan Ekonomi Percepatan Pelaksanaan Berusaha, http://finansial.bisnis.com/read/2017 0831/9/685850/pemerintahluncurkan-paket-kebijakan-ekonomipercepatan-pelaksanaan-berusaha, diakses pada tanggal 9 Juni 2018 pukul 10.52 WIB.

Nuria Siswi Enggarani, 2016, Kualitas Pelayanan Publik dalam Perizinan di Pelayanan Terpadu Satu Pintu (PTSP) Kantor Badan Penanaman Modal dan Pelayanan Perizinan Terpadu (BPMP2T) Kabupaten Boyolali, Jurnal Law and Justice Fakultas Hukum Universitas Muhammadiyah Surakarta, Vol. 1 No. 1.

Raisa Harly Runida Agustine, 2014, Pengaturan Pelayanan Perizinan Terpadu Satu Pintu Dalam Upaya Meningkatkan Investasi Di Provinsi Lampung, Jurnal HIMA HAN Fakultas Hukum Bagian Hukum Administrasi Negara Universitas Lampung, Vol. 1, No. 1.

Ronni Juwandi, 2016, Efektivitas Badan Pelayanan Perizinan Terpadu Kota Bandung Dalam Rangka Reformasi Birokrasi, Untirta Civic Education Journal ( UCEJ ), Vol. 1, No. 2, Desember.
Samsul Rizal, Pernyataan Rektor Universitas Syiah Kuala (Unsyiah) Darussalam Banda Aceh, di Acara Wisuda AAC Dayan Dawood Darussalam, Banda Aceh, diakses pada http://www.republika.co.id/berita/ pendidikan/duniakampus/15/08/27/ntpdoq334rektor pengusaha-di-indonesia165-persen-singapura-7-persenpenduduk, diakses pada tanggal Kamis 27 Augustus 2015, 14:15 WIB.

Septian Deny, Investasi di Sragen Alami Peningkatan Signifikan, dibuat pada 15 Juni 2015, 14:53 WIB, diakses pada https://www.liputan6.com/bisnis/r ead/2252172/investasi-di-sragenalami-peningkatan-signifikan, diakses pada tanggal 6 Juli 2018 Pukul 15:57 WIB.

Sri Agustina Rumapea dan Kridanto Surendro, 2007, Perencanaan Arsitektur Enterprise Penyelengaraan Pelayanan Terpadu Satu Pintu (Usulan: Dinas Perizinan), Seminar Nasional Aplikasi Teknologi Informasi (SNATI 2007); Pelayanan Satu Pintu Plus di Kabupaten Solok.

Suwari Akhmaddhian, 2012, Pengaruh Reformasi Birokrasi Terhadap Perizinan Penanaman Modal Di Daerah (Studi Kasus Di Pemerintahan Kota Bekasi), Jurnal Dinamika Hukum, Vol. 12 No. 3, September. 